\title{
Nutrient Concentration Changes in Oriental Kabakulak Tobacco during the Growing Season*
}

\author{
by Vasilios A. Mylonas \\ Department of Agronomy, Tobacco Institute, Drama, Greece
}

\section{SUMMARY}

A three-year field study with Oriental Kabakulak ( $\mathrm{Ni}$ cotiana tabacum L. cv. Kabakulak-S ${ }_{2}$ ) was conducted on a sandy clay loam soil at Drama, Greece, to determine nutrient concentration patterns in tobacco plants. All cultural practices were those in use for commercial production of Oriental neutral type tobacco. Whole tobacco plants were sampled at weekly intervals from transplanting to the end of the harvesting season and separated into leaves, stalks and roots. The samples were washed, dried, weighed, ground, and analyzed for nitrogen, phosphorus, potassium, calcium and magnesium.

Nitrogen and potassium concentrations in leaves, stalks and roots tended to decrease during the 1st week after transplanting, then increased up to the 3 rd or 4 th week and declined thereafter. Phosphorus concentration in all plant parts decreased with time after transplanting. This decrease was greater during the first two weeks than later on. Calcium concentration in leaves and stalks increased from the first to the 2 nd or 3 rd week, then declined slowly up to the 8 th week and remained constant thereafter. In roots, calcium decreased from the 1 st to the 8th week and then remained constant. Magnesium concentration in leaves increased from the 1 st to the 4th week and then remained constant. In stalks, magnesium increased from transplanting to the 2 nd week and then declined slightly, whereas in roots magnesium decreased after the 1st week. Concentrations of nitrogen, potassium and calcium in leaves were similar and much higher than those of magnesium and phosphorus.

\footnotetext{
* Received: 12th February 1982 - accepted: 18th October 1983
}

\section{ZUSAMMENFASSUNG}

Ūber einen Zeitraum von drei Jahren wurde in Drama, Griechenland, auf sandigem, tonigem Lehmboden mit Orienttabak (Nicotiana tabacum L., cv. Kabakulak-S ${ }_{2}$ ) ein Feldversuch mit dem Ziel durchgeführt, die Nāhrstoffverteilung in der Tabakpflanze zu bestimmen. Die Pflanzen wurden entsprechend den für handelsüblichen neutralen Orienttabak üblichen landwirtschaftlichen Methoden angebaut. Von der Zeit des Verpflanzens ins Freiland an bis zum Ende der Erntezeit wurden einmal wöchentlich Tabakpflanzen im ganzen als Proben gezogen und in Blattgut, Stengel und Wurzeln aufgetrennt. Die Proben wurden gewaschen, getrocknet, gewogen, gemahlen und auf Stickstoff, Phosphor, Kalium, Calcium und Magnesium untersucht.

Der Gehalt an Stickstoff und Kalium in Blattgut, Stengel und Wurzeln nahm in der 1 . Woche nach dem Umpflanzen eher ab, stieg dann bis zur 3. und 4. Woche an und fiel danach wieder ab. Der Phosphorgehalt nahm in allen Pflanzenteilen nach dem Umpflanzen $a b$, und zwar in den ersten beiden Wochen in stärkerem Maße als danach. Der Gehalt an Calcium in Blattgut und Stengel stieg von der 1. bis zur 2. und 3. Woche an, ging dann bis zur 8. Woche langsam zurück und veränderte sich danach nicht mehr. In den Wurzeln nahm der Calciumgehalt von der 1 . bis zur 8 . Woche ab und blieb dann konstant. Der Magnesiumgehalt nahm im Blattgut von der 1. bis zur 4 . Woche zu und veränderte sich danach nicht mehr; im Stengel stieg er vom Umpflanzen bis zur 2. Woche an und ging dann leicht zurück, während er in den Wurzeln nach der 1. Woche abnahm. Im Blattgut war der Gehalt an Stickstoff, Kalium und Calcium gleich groß oder wesentlich größer als der $\mathrm{Ge}$ balt an Magnesium und Phosphor. 


\section{RESUME}

Un essai de plein champ a été effectué pendant une durée de trois ans à Drama en Grèce à l'aide de tabac d'Orient (Nicotiana tabacum L., cv. Kabakulak-S ${ }_{2}$ ) cultivé sur un sol de glaise argileux et sablonneux. Cet essai avait pour but la détermination de la répartition des matières nutritives dans une plante de tabac. Ces plantes ont été cultivées conformément aux méthodes agricoles utilisées habituellement pour le tabac d'Orient neutre en vente dans le commerce. Depuis la transplantation en plein champ jusqu'à la fin de la récolte, on préleva une fois par semaine des plantes de tabac entières pour servir d'échantillons, répartis en feuille, tige et racine. Ceux-ci étaient lavés, séchés, pesés, moulus et analysés quant à leur teneur en azote, phosphore, potassium, calcium et magnésium.

Une semaine après la transplantation, la teneur en azote et potassium des feuilles, tiges et racines eut tendance à baisser. Elle augmenta par contre jusqu'à la troisième et quatrième semaine puis baissa à nouveau. Après la transplantation, la teneur en phosphate baissa dans toutes les parties de la plante et cela davantage durant les deux premières semaines qu'ultérieurement. La teneur en calcium des feuilles et des tiges augmenta de la première à la deuxième et troisième semaine puis baissa lentement jusqu'à la huitième semaine pour ne plus se modifier. La teneur en calcium des racines baissa de la première à la huitième semaine puis demeura constante. La teneur en magnésium augmenta dans les feuilles de la première à la quatrième semaine pour ne plus se modifier ultérieurement. Elle augmenta par contre dans les tiges du moment de la transplantation jusqu'à la deuxième semaine puis baissa légèrement tandis qu'elle baissa dans les racines après la première semaine. La teneur en azote, potassium et calcium des feuilles était égale ou bien supérieure à celles en magnésium et phosphore.

\section{INTRODUCTION}

The successful production of a high quality tobacco crop is dependent on understanding its vegetative growth pattern and nutrient uptake throughout the growing season. The growth at all stages and the nutrient concentration of field-grown tobacco are influenced by the class and the variety of tobacco, fertilization, spacing, soil moisture, topping, rainfall and other cultural practices and environmental and soil factors (1,
3, 5, 8). Unless there are other restrictive factors, growth rates and nitrogen concentration generally increase as the concentration of available soil nitrogen increases from deficient to adequate (8). Also the nitrogen form affects the growth and concentration of nitrogen, phosphorus, potassium, calcium and magnesium in tobacco plants (13). Dry matter and nutrient accumulation in plant tissue studies with flue-cured, Burley, Maryland and wrapper tobacco have been reported on $(1,2,5,6,7,10,11,12)$. Concentrations of plant nutrients in various plant parts have been studied in other crops (5).

Although data on fertilization practices with Oriental tobacco have been published, studies on the concentration of plant nutrients during the growing season in Oriental tobacco are not known. The present investigation was conducted to determine the concentration of nutrients in leaves, stalks and roots during the growing season of a commercial variety of Oriental neutral type tobacco grown in the field.

\section{MATERIALS AND METHODS}

Nicotiana tabacum L. cv. Kabakulak-S, an Oriental neutral type tobacco, was grown in the field in 1976, 1978 and 1979 at the Experimental Farm of the Tobacco Institute of Greece in Drama. The soil texture and certain chemical characteristics of soils used for this study are given in Table 1 . Soil samples $(0-20 \mathrm{~cm}$ depth) were taken prior to fertilization. Soil phosphorus was determined by Olsen's procedure (9), potassium by Dirk's procedure (4), and calcium and magnesium were determined by atomic absorption spectroscopy in water extract. Fertilizers were broadcast on the soil surface a few days before transplanting and were incorporated into the top $12 \mathrm{~cm}$ of soil. Nitrogen was applied at $40 \mathrm{~kg} \mathrm{~N} / \mathrm{ha}$, phosphorus at $40 \mathrm{~kg} \mathrm{P} / \mathrm{ha}$ and potassium at $80 \mathrm{~kg} \mathrm{~K} / \mathrm{ha}$. Seventy percent of this preplant applied nitrogen was in ammonium form and $30 \%$ in nitrate form (ammonium sulfate, ammonium nitrate). Phosphorus was applied as monocalcium phosphate and potassium as potassium sulfate. Three weeks after transplanting $20 \mathrm{~kg} \mathrm{~N} / \mathrm{ha}$ from ammonium nitrate were applied as a side-dressing.

Plant spacing was $55 \mathrm{~cm}$ between rows and $15 \mathrm{~cm}$ in the row. Plot size was $11.0 \mathrm{~m} \times 4.95 \mathrm{~m}=54.45 \mathrm{~m}^{2}$. Seedlings were transplanted between 20th and 25th May each year. Other cultural practices were those normally used by growers in Greece. The experimental plots were

Table 1. Some characteristics of soils used.

\begin{tabular}{l|l|c|c|c|c|c|c}
\hline Year & Textural class & $\mathrm{pH}$ & $\begin{array}{c}\text { Organic } \\
\text { matter } \\
(\%)\end{array}$ & $\begin{array}{c}\mathrm{P} \\
(\mathrm{ppm})\end{array}$ & $\begin{array}{c}\mathrm{K} \\
(\mathrm{ppm})\end{array}$ & $\begin{array}{c}\mathrm{Ca} \\
(\mathrm{ppm})\end{array}$ & $\begin{array}{c}\mathrm{Mg} \\
(\mathrm{ppm})\end{array}$ \\
\hline 1976 & Sandy loam & 7.3 & 0.68 & 13.3 & 15.0 & 26.5 & 4.8 \\
1978 & Sandy clay loam & 7.2 & 0.83 & 18.0 & 21.3 & 22.4 & 5.0 \\
1979 & Sandy clay & 7.6 & 1.00 & 4.6 & 18.8 & 25.3 & 4.4 \\
\hline
\end{tabular}


irrigated when the available soil moisture was limiting tobacco growth. Three irrigations were applied in 1976 and 1978 and two in 1979.

Samples of whole plants were taken from each of the 12 replications every week, after transplanting throughout the growing season, for dry matter accumulation and chemical analysis. Fifty plants were sampled in each of 12 replications in the 1 st week after transplanting, 40 plants in the 2 nd week, 30 plants in the 3 rd week, 20 plants in the 4th week, 10 plants in the 5th week and thereafter six plants per plot per sampling. Plants sampled after the 4th week were protected by guard plants. The soil was washed from the roots, lower leaves and base of the stalk. The whole plants were washed with tap water, separated into leaves, stalks (stalk plus flower) and roots, washed with deionized water, dried at $65^{\circ} \mathrm{C}$ for 48 hours, weighed and stored. Mature leaves were harvested in primings from each plant, in accordance with normal production practices and were identified, washed with tap water and then with deionized water, dried at $65^{\circ} \mathrm{C}$ for 48 hours, weighed and later composited with the remaining leaves of the sampled plants. The various plant parts were ground after redrying at $65^{\circ} \mathrm{C}$ in a Wiley mill to pass a $1 \mathrm{~mm}$ sieve for chemical analysis.

Nitrogen, phosphorus, potassium, calcium and magnesium were determined on leaf, stalk and root samples each year and expressed as percentage of dry matter of leaves, stalks and roots of tobacco plants. Total nitrogen was determined by the Kjeldahl procedure, modified to include $\mathrm{NO}_{3}-\mathrm{N}$. Plant samples were dryashed at $500^{\circ} \mathrm{C}$. The residue was dissolved with a mixture of $1: 1 \mathrm{HCl}$ : distilled water and phosphorus, potassium, calcium and magnesium contents of the filtrate were determined. Phosphorus was determined colorimetrically by the molybdovanadate procedure, potassium by atomic emission spectroscopy and calcium and magnesium by atomic absorption spectroscopy using a Perkin-Elmer 403 spectrophotometer. Nutrient concentrations were averaged over all replications and over the three years. Tobacco of the same variety, grown adjacent to the study plots and under the same management practices, was used as a reference for yield and quality data. The leaves of these plots were harvested in six primings, sun-cured, sorted, weighed and graded. The yield of sun-cured leaves was $1880 \mathrm{~kg} / \mathrm{ha}$ and the tobacco quality was very good.

\section{RESULTS AND DISCUSSION}

Some of the climatic data from the Experimental Farm, where this study was conducted, are presented in Table 2. The low mean air temperature in May probably had some decelerating effects on root establishment of tobacco plants after transplanting. Precipitation was not distributed uniformly during the tobacco growing season. The rainfall had three peaks, two in May and one in July with $33 \mathrm{~mm}, 41 \mathrm{~mm}$ and $40 \mathrm{~mm}$, respectively. These rainfalls supplied adequate water for growth of
Figure 1. Nitrogen concentration In leaves, stalks and roots of tobacco plants grown in the field (average of the three years 1976, 1978, 1979).

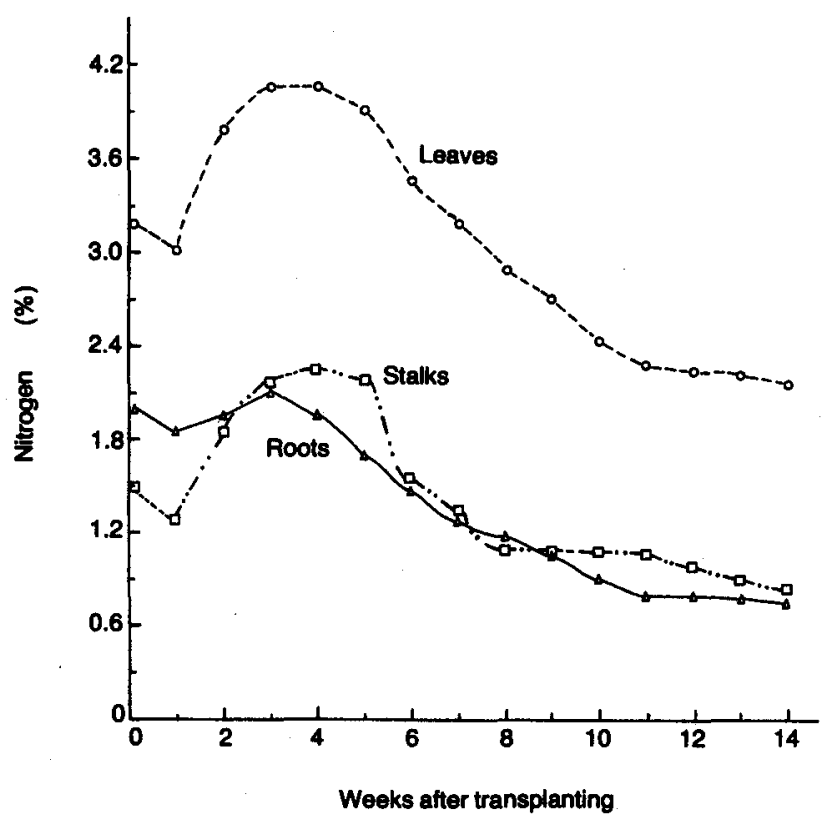

Oriental tobacco. The other rainfalls that occurred were lower than $20 \mathrm{~mm}$ and provided only part of the water that tobacco plants needed for good growth. The rest of the water required was supplied by irrigation. Hours of sun in Drama are generally high and result in a high rate of photosynthesis and very good conditions for tobacco curing.

Nitrogen concentrations in leaves, stalks and roots are shown in Fig. 1. Generally, nitrogen concentration in leaves was higher than in stalks and/or in roots. In leaves, nitrogen concentration increased from $3.02 \%$ to $4.07 \%$ (least significant difference at $p=0.05: 0.43$ ) from the 1 st

Table 2. Alr temperature, sunshine and rainfall in Drama (average of the three years 1976, 1978, 1979).

\begin{tabular}{l|r|r|r|r}
\hline Month & Date & $\begin{array}{c}\text { Mean air } \\
\text { temperature } \\
\left({ }^{\circ} \mathrm{C}\right)\end{array}$ & $\begin{array}{c}\text { Sunshine } \\
\text { (hours/day) }\end{array}$ & $\begin{array}{r}\text { Total rainfall } \\
(\mathbf{m m})\end{array}$ \\
\hline May & $1-10$ & 18.4 & 8.2 & 4.4 \\
& $11-20$ & 16.9 & 6.9 & 32.6 \\
& $21-31$ & 19.0 & 6.9 & 40.8 \\
June & $1-10$ & 20.5 & 8.1 & 1.9 \\
& $11-20$ & 25.3 & 9.8 & 5.1 \\
& $21-30$ & 24.1 & 8.6 & 16.9 \\
July & $1-10$ & 25.4 & 9.4 & 4.2 \\
& $11-20$ & 25.1 & 10.4 & 15.6 \\
& $21-31$ & 23.9 & 9.5 & 40.0 \\
August & $1-10$ & 24.7 & 9.8 & 7.0 \\
& $11-20$ & 22.3 & 8.8 & 19.3 \\
& $21-31$ & 21.8 & 7.5 & 18.1 \\
& $1-10$ & 20.7 & 8.2 & 13.0 \\
September & $11-20$ & 19.7 & 8.2 & 17.9 \\
& $21-30$ & 19.1 & 7.6 & 16.3 \\
\hline
\end{tabular}


Figure 2. Phosphorus concentration in leaves, stalks and roots of tobacco plants grown in the fleld (average of the three years 1976, 1978, 1979).

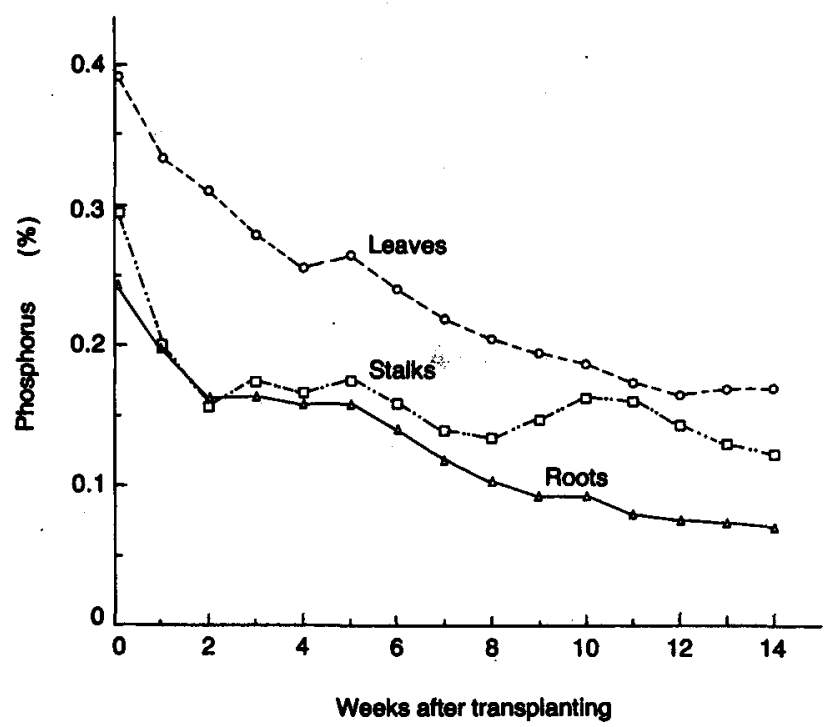

to the 3 rd week after transplanting and then decreased to $2.14 \%$ at the end of the growing season.

The nitrogen concentration after the 1st week, when transplants had established new roots, increased up to the 3rd week as a result of increased nitrogen uptake due to increasing root system and low rate of leaf growth. These optimum nutritional conditions are actually essential during the first three weeks after transplanting, since during this period the activity of the leaves increases to its maximum, by affecting cell division and elongation in the emerging leaves (7).

From the 4th to the 11th week after transplanting, leaf nitrogen concentration decreased. This may be explained in part by the high leaf growth rate compared to that of roots for the period from the 4th to the 9th week and by diminishing available soil nitrogen in later growing season. At the 8th week after transplanting, when harvesting started, the nitrogen concentration was $2.91 \%$ and decreased thereafter as plants flowered and progressed to maturity. After the 11 th week, leaf nitrogen concentration remained unchanged, whereas stalk nitrogen concentration decreased and there was probably a movement of nitrogen from the stalk to the leaves. Similar results have been reported for flue-cured tobacco by Gopalachari et al. (6). In similar studies with Burley tobacco, nitrogen concentration decreased significantly from the 6 th to the 12 th week after transplanting (12), or tended to decrease very little from the 4th to 10th week after transplanting and remained constant thereafter (7). The lower leaf nitrogen concentration in Oriental tobacco at harvesting time compared to that of the previous growth stages is in agreement with diminished nitrogen uptake during harvesting in the other tobacco classes.

Nitrogen concentration in stalks increased from $1.31 \%$ to $2.24 \%$ (least significant difference at $p=0.05: 0.17$ )
Figure 3. Potassium concentration in leaves, stalks and roots of tobacco plants grown in the field (average of the three years 1976, 1978, 1979).

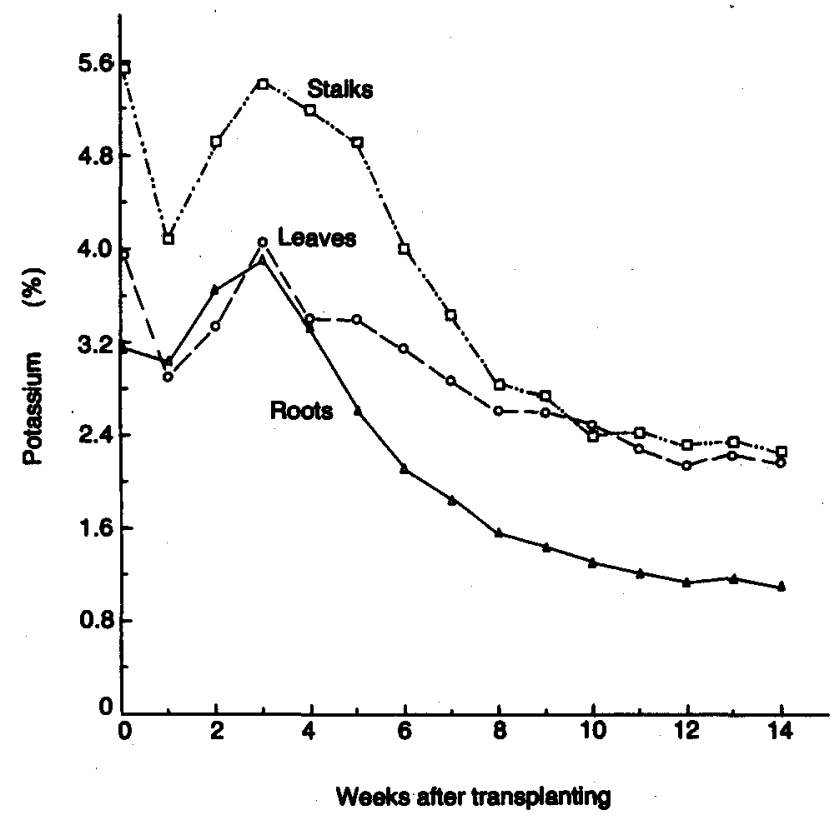

from the 1st to the 4th week after transplanting and then declined to $0.84 \%$ at the 14 th week. Nitrogen concentration in Burley stalk decreased from the 4th to the 10th week after transplanting (topping time), but remained constant thereafter (7). Nitrogen concentration in roots increased from $1.87 \%$ to $2.09 \%$ (least significant difference at $p=0.05: 0.22$ ) from the 1 st to the 3rd week after transplanting and then declined to $0.76 \%$ at the end of the growing season.

Phosphorus concentrations in leaves, stalks and roots are presented in Fig. 2. The phosphorus concentration of leaf tissue was higher than that of stalk tissue which, in turn, was higher than that of root tissue, but the curve for leaves was parallel to that for roots for most of the growing season. Generally, in all plant parts there was a decrease in phosphorus concentration from transplanting to the end of growing season, ranging in leaves from $0.39 \%$ to $0.17 \%$ (least significant difference at $p=0.05: 0.03$ ), in stalks from $0.30 \%$ to $0.12 \%$ (least significant difference at $p=0.05: 0.04$ ) and in roots from $0.24 \%$ to $0.07 \%$ (least significant difference at $p=0.05: 0.01$ ). In studies with flue-cured tobacco, leaf phosphorus concentration decreased from $0.41 \%$ at transplanting to $0.15 \%$ at the 17 th week (6). Phosphorus concentration in all plant parts decreased rapidly during the first two to four weeks after transplanting. It is suggested that this is a dilution effect since the soil temperature is low and the root system of tobacco plants is restricted during the first weeks after transplanting. These factors affect phosphorus absorption by the plants (8). Plant water stress, too, has been reported to reduce phosphorus concentration in leaves of sorghum plants (5).

Potassium concentration in leaves (least significant difference at $p=0.05: 0.39$ ) and stalks (least significant difference at $p=0.05: 0.80$ ) decreased for the 1 st week after 
Figure 4. Calclum concentration in leaves, stalks and roots of tobacco plants grown in the fleld (average of the three years 1976, 1978, 1979).

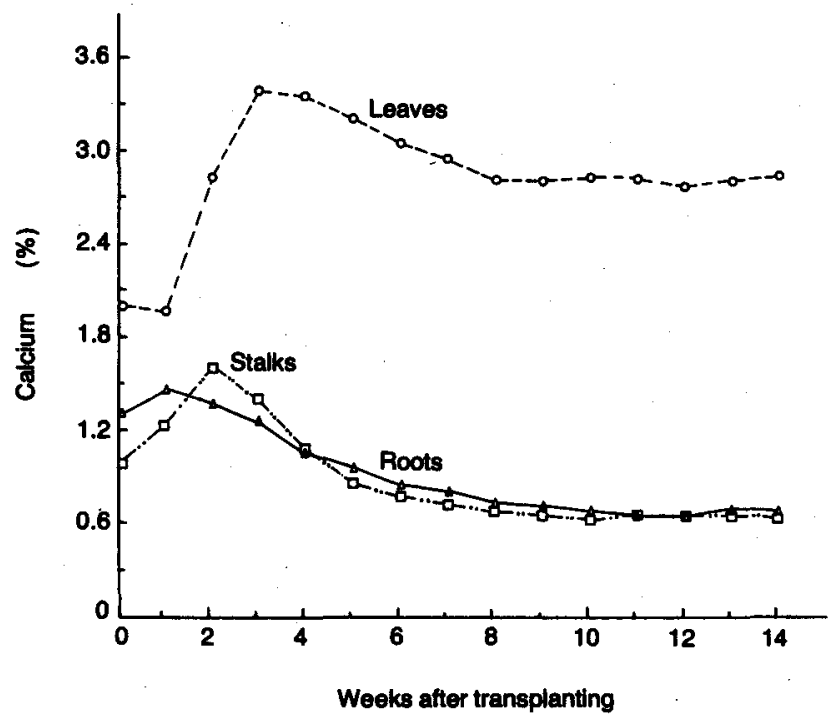

transplanting (Fig. 3), then increased until the 3rd week and again declined until the end of the growing season. The concentration in stalks $(5.40 \%)$ was higher than that in leaves $(4.06 \%)$ at the first stages of plant growth. This difference decreased with time after the 4th week from transplanting. But after the 8th week from transplanting, when harvesting started, potassium concentrations in leaves and stalks were similar. In the first stages of growth, tobacco plants absorb more potassium than is needed and part of it is stored in stalks (8). During harvesting, potassium from the stalks probably moved to the leaves. In leaves of flue-cured tobacco potassium concentration increased from $2.99 \%$ at transplanting to $4.27 \%$ at the 4th week and decreased to $1.38 \%$ at the 17 th week (6). Potassium concentration in roots increased from $3.03 \%$ (least significant difference at $p=0.05: 0.51$ ) at the 1 st week after transplanting to about $3.90 \%$ at the 3 rd week and then declined to $1.10 \%$ at the end of the growing season. Potassium concentration in stalks was higher than that in roots but the curves for stalks and roots were parallel during the growing season. This indicated that potassium from the roots moved readily to the stalks.

The calcium concentration in leaves was higher than that in stalks and/or in roots (Fig. 4). Calcium concentration in leaves increased from $1.98 \%$ (least significant difference at $p=0.05: 0.41$ ) at the 1 st week after transplanting to $3.40 \%$ at the 3 rd week, then declined to $2.86 \%$ at the 8 th week and thereafter remained constant during the harvesting season. Calcium concentration in stalks increased from $1.00 \%$ at transplanting to $1.62 \%$ (least significant difference at $p=0.05: 0.19$ ) at the 2 nd week after transplanting and then declined to $0.65 \%$ at the end of the growing season. The curve of calcium concentration in roots was similar to that for stalks. Calcium concentration of flue-cured leaf tissue decreased from $2.70 \%$
Figure 5. Magnesium concentration In leaves, stalks and roots of tobacco plants grown in the field (average of the three years 1976, 1978, 1979).

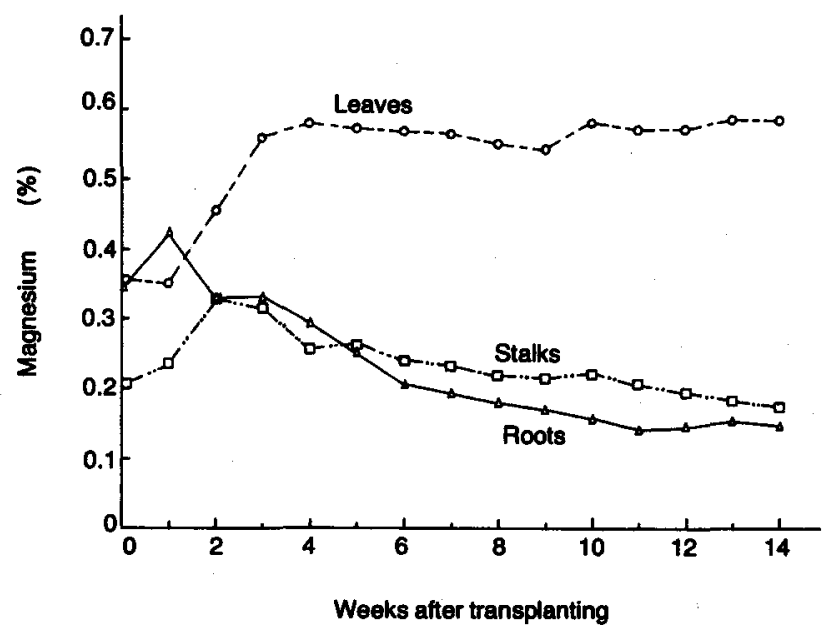

at transplanting to $1.79 \%$ at the 9 th week and then increased to $2.22 \%$ at the 17 th week after transplanting (6). The calcium concentration of tobacco leaf depends on the available soil calcium and soil $\mathrm{pH}$. The soils used in this study were rich in available calcium and their $\mathrm{pH}$ ranged from 7.2 to 7.6 (Table 1). The data indicated that most of the calcium taken up by the roots translocated through the stalk to the leaves, in which calcium concentration was much higher than that in roots or stalks for the period from the 3rd week to the end of the growing season.

Magnesium concentration in leaves was higher than that in stalks or roots (Fig. 5). Leaf magnesium concentration increased from $0.35 \%$ at the 1 st week after transplanting to $0.58 \%$ (least significant difference at $p=0.05: 0.13$ ) at the 4th week, and then remained relatively constant until the end of the growing season. Stalk magnesium concentration increased from $0.20 \%$ (least significant difference at $\mathrm{p}=0.05: 0.07$ ) after transplanting to $0.33 \%$ at the 2 nd week and then declined to $0.17 \%$ at the end of season. Magnesium concentration in roots decreased from $0.42 \%$ (least significant difference at $p=0.05: 0.08$ ) at the $1 \mathrm{st}$ week to $0.15 \%$ at the end of the growing season.

It is very interesting to note that nitrogen, phosphorus, calcium and magnesium concentrations in stalks and roots were generally similar and parallel throughout the growing season (Figures 1, 2, 4 and 5), whereas potassium concentrations in stalks were higher than in roots, but parallel (Figure 3). The concentrations of all determined nutrients in leaves during the growing season are presented in Figure 6. Concentration patterns for nitrogen, potassium and calcium were very similar, with calcium concentration being lower than those of nitrogen and pottasium during the first half and higher during the second half of the growing season. Phosphorus concentration was the lowest of the determined nu- 
Figure 6. Nitrogen, phosphorus, potassium, calclum and magnealum concentrations in leaves of tobacco plants grown In the field (average of the three years 1976, 1978, 1979).

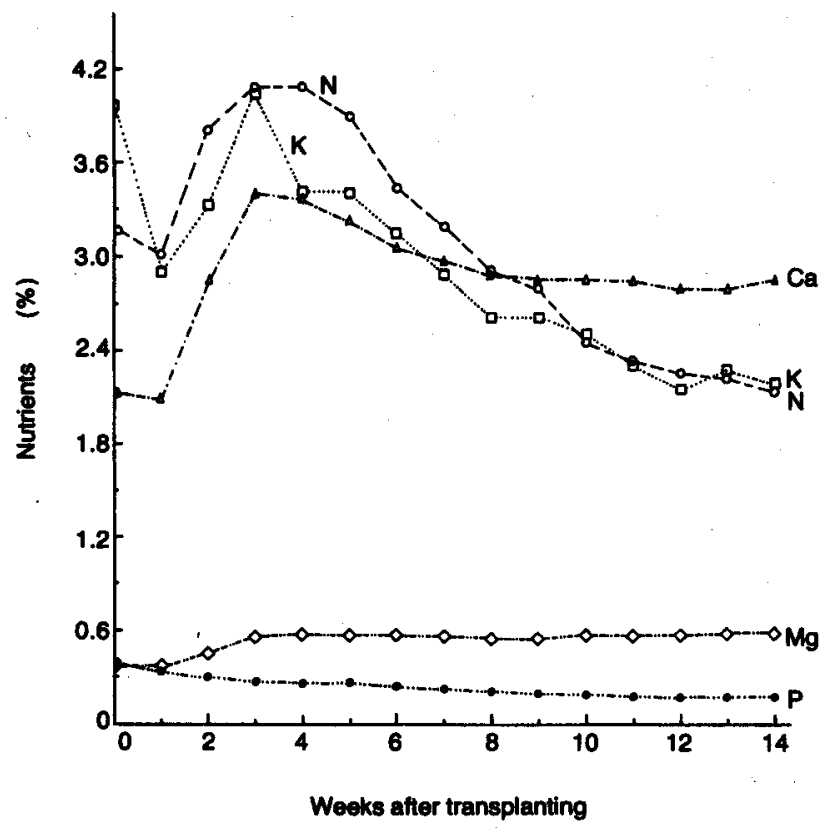

trients in leaves and decreased slowly but steadily from transplanting to the end of the growing season. Magnesium concentration which was twice as high as that of phosphorus, remained constant after the 3rd week from transplanting.

Generally, phosphorus and magnesium concentration patterns were straight lines compared to those of nitrogen, potassium and calcium, which were sigmoid. Nitrogen, potassium and calcium concentrations in leaves were about six times higher than magnesium concentration in the 2nd to 5th week and four to five times higher later on. Leaf potassium concentration was 10 to 14 times higher than that of phosphorus during the growing season. In spite of this, in fertilization practices applied phosphorus is $40 \%$ to $50 \%$ of that of applied potassium, resulting in high phosphorus residual effects and increased available soil phosphorus in tobacco fields. It is suggested that tobacco farmers should apply less phosphorus fertilizer in fields ,with high phosphorus availability.

\section{REFERENCES}

1. Bertinuson, T. A., E. Larssen, B. Teveris, M. G. Comfort and M. Petersen: Nutrient uptake and dry matter accumulation of Connecticut shadegrown wrapper tobacco for three consecutive years; Tob. Sci. 14 (1970) 155-157.

2. Botha, A. D. P.: Determination of the uptake of nitrogen by tobacco plants during their growing period, using the nitrogen isotope ${ }^{15} \mathrm{~N}$; S. Afr. J. Agric. Sci. 8 (1965) 449-454.
3. Bowman, D. R., and B. C. Nichols: Composition of Burley tobacco leaves in relation to stalk position and leaf portion; Tob. Sci. 12 (1968) 91-94.

4. Dirks, B., and F. Scheffer: Z. Pflanzenern., Düngung und Bodenk. 1933, 428.

5. Eck, H. V., and J. T. Musick: Plant water stress effects on irrigated grain sorghum, II. Effects on nutrients in plant tissues; Crop Sci. 19 (1979) 592-598.

6. Gopalachari, N. C., M. C. Manga Reddy and K. L. Narasaiah: Dry matter production and nutrient uptake by flue-cured tobacco at different stages of growth in representative light and heavy soils of Andhva Pradesh; Tob. Res. 4 (1978) 6-11.

7. Kroontje, W., A. Badr and H. C. H. Hahne: Growth pattern of Burley 21 tobacco and associated nitrogen and nicotine levels in plant parts; Tob. Sci. 16 (1972) 46-51.

8. McCants, C. B., and W. G. Woltz: Growth and mineral nutrition of tobacco; Advances in Agronomy 19 (1967) 211-265.

9. Olsen, S. R., C. V. Cole, F. S. Watanabe and L. A. Dean: Estimation of available phosphorus in soils by extraction with sodium bicarbonate; U. S. Dept. Agr. Circ. 939, 1954.

10. Raper, C. D., Jr., and C. B. McCants: Nutrient accumulation in flue-cured tobacco; Tob. Sci. 11 (1967) 190.

11. Schmidt, J. A.: Feststellung des Nährstoffentzugs der deutschen Tabaksorten; Dtsch. Tabakbau 55 (1973) 33-37.

12. Sims, J. L., and W. O. Atkinson: Accumulation of dry matter and nicotine content of Burley tobacco growing in fertilizer-induced acid soil; Agron. J. 65 (1973) 762-765.

13. Skogley, E. O., and C. B. McCants: Ammonium and chloride on growth characteristics of flue-cured tobacco; Soil Sci. Soc. Am. Proc. 27 (1963) 391-394.

\section{Acknowledgements}

Thanks are expressed to E. Pangos, Agronomist, for bis belp in carrying out this study, to the Department of Chemistry of the Tobacco Institute of Greece for nitrogen determination, to P. Margioridou and C. Giortsion for running laboratory analysis and to A. Ourowmis for technical assistance.

Author's address:

Department of Agronomy,

Tobacco Institute,

Drama, Greece. 